WIDYA BIOLOGI

\title{
HIPERURISEMIA SEBAGAI FAKTOR RISIKO PENYAKIT KARDIOVASKULAR MELALUI MEKANISME STRES OKSIDATIF
}

\section{(HYPERURISEMIA AS A RISK FACTOR OF CARDIOVASCULAR DISEASE THROUGH OXIDATIVE STRESS MECHANISM)}

\author{
I Made Sumarya $^{1}$ \\ ${ }^{1}$ Program Studi Biologi, FTIS, Universitas Hindu Indonesia \\ Email: sumaryaimade@yahoo.com
}

\begin{abstract}
Hyperuricemia has been known for a long time, and received medical attention because it is associated with various diseases such as high blood pressure, atherosclerosis, kidney disease, diabetes mellitus and cardiovascular disease. This relationship might have a significant cause however, there is no clear mechanism of hyperuricemia causing cardiovascular disease. Hyperuricemia is a risk factor for cardiovascular disease by providing direct vascular effects and causing vascular damage. Based on the results of the study it is known that uric acid causes endothelial proliferation, angiotensin II production and increased oxidative stress (ROS). Uric acid at high concentrations (hyperuricemia) causes oxidative stress by increasing ROS formation, inducing vascular changes through the activation of redox sensitive signaling pathways activating mitogen activated protein kinases (MAPKs), tyrosine kinases and transcription factors (NFKB, AP-1, and HIF-1) stimulates the formation of monocyte chemoattractant protein-1 (MCP-1), inflammation and increases cyclooxygenase 2 (COX-2). Hyperuricemia as a risk factor for cardiovascular disease is related to inflammatory activity, activation of the angiotensin aldosterone rennin system (RAAS), endothelial dysfunction, proliferation of vascular smooth muscle cells (VSMC) and high blood pressure. Conclusion: hyperuricemia as a risk factor for cardiovascular disease that is by causing vascular damage through an increased mechanism of ROS formation, activating mitogen activated protein kinase (MAPKs), tyrosine kinase and transcription factors (NFKB, AP-1, and HIF-1) stimulates the formation of monocyte chemoattractant proteins $-1(M C P-1)$, inflammation and increase cyclooxygenase 2 (COX-2).
\end{abstract}

Keywords: Hyperuricemia, oxidative stress, cardiovascular disease

\begin{abstract}
ABSTRAK
Hiperurisemia sudah dikenal sejak dahulu, dan mendapat perhatian medis karena berhubungan dengan berbagai penyakit seperti tekanan darah tinggi, aterosklerosis, penyakit ginjal, diabetes melitus dan penyakit kardiovaskular. Hubungan ini mungkin memiliki penyebab yang signifikan namun, tidak ada mekanisma yang jelas hiperurisemia menyebabkan penyakit kardiovaskular. Hiperurisemia sebagai faktor risiko penyakit kardiovaskular dengan memberikan efek vaskular secara langsung dan menyebabkan kerusakan vaskular. Berdasarkan hasil-hasil penelitian diketahui bahwa Asam urat menyebabkan proliferasi endotel, produksi angiotensin II dan peningkatan stres oksidatif (ROS). Asam urat pada konsentrasi tinggi (hiperurisemia) menimbulkan stress oksidatif dengan meningkatkan pembentukan ROS, menginduksi perubahan vaskular melalui aktivasi jalur sinyal sensitif redoks mengaktifkan mitogen activated protein kinase $(M A P K s)$, tirosin kinase dan faktor transkripsi $\left(N F_{K} B, A P-1\right.$, dan HIF-1) merangsang
\end{abstract}




\section{WIDYA BIOLOGI}

pembentukan monocyte chemoattractant protein-1 (MCP-1), inflamasi dan meningkatkan siklooksigenase 2 (COX-2). Hiperurisemia sebagai faktor risiko penyakit kardiovaskular terkait dengan aktivitas inflamasi, aktivasi sistim rennin angiotensin aldosteron (RAAS), disfungsi endotel, proliferasi vascular smooth muscle cell (VSMC) dan tingginya tekanan darah. Simpulan: hiperurisemia sebagai faktor risiko penyakit kardiovaskular yaitu dengan menyebabkan kerusakan vaskular melalui mekanisma peningkatan pembentukan ROS, mengaktifkan mitogen activated protein kinase (MAPKs), tirosin kinase dan faktor transkripsi $\left(N F_{K} B, A P-1\right.$, dan HIF-1) merangsang pembentukan monocyte chemoattractant protein-1 (MCP-1), inflamasi dan meningkatkan siklooksigenase 2 (COX2).

Kata Kunci : Hiperurisemia, stres oksidatif, penyakit kardiovaskula.

\section{PENDAHULUAN.}

Hiperurisemia adalah suatu keadaan di mana kadar asam urat yang tinggi di dalam darah, yaitu melebihi $7 \mathrm{mg} / \mathrm{dL}$ (420 $\mu \mathrm{M})$ pada pria dan $6 \mathrm{mg} / \mathrm{dL}(360 \mu \mathrm{M})$ pada wanita (Feig et al., 2008). Hiperurisemia sudah dikenal sejak dahulu, dan mendapat perhatian medis pertama kali ketika Garrod menemukannya sebagai penyebab gout sekitar dua abad yang lalu yaitu di awal 1800an (Nakagawa et al., 2006; Alderman, 2008). Hal ini karena lebih dari $50 \%$ pasien gout menderita hipertensi, seperempatnya memiliki penyakit ginjal dan sebagian besar menderita penyakit jantung (Alderman, 2008). Penelitian epidemiologi menemukan bahwa asam urat yang tinggi (hiperurisemia) berhubungan dengan tekanan darah tinggi, aterosklerosis, penyakit ginjal, penyakit kardiovaskular dan diabetes melitus (Alderman, 2008; Feig et al., 2008; Kanbara et al., 2010). Tingginya kadar asam urat umumnya berhubungan dengan peningkatan risiko penyakit kardiovaskular. Selanjutnya penelitian eksperimental baru-baru ini menyimpulkan bahwa asam urat dapat memiliki peran kausal dalam hipertensi dan metabolik sindrom. Semua kondisi ini dikatakan dimediasi oleh stres oksidatif
(Sautin et al., 2007). Selain itu, prevalensi hiperurisemia cenderung semakin meningkat, maka dikakhawatirkan tentang potensi bahayanya juga semakin meningkat (Wallace et al., 2004; Alderman, 2008).

Penelitian terbaru menyimpulkan bahwa hiperurisemia merupakan faktor risiko independen penyakit kardiopaskular (Gagliardi et al., 2009; Tomiyama et al., 2011), metabolik sindrom (Oliviera and Burini, 2012) dan penyakit diabetes mellitus (Samant et al., 2012). So and Thorens, (2010) mengungkapkan bahwa hiperurisemia dapat memberikan efek vaskular secara langsung dan memberikan kecenderungan untuk terjadinya disfungsi sel endotel (ECD). Bebeberapa penelitian lain juga menyim-pulkan bahwa hiperurisemia merupakan faktor penyebab dari kerusakan vascular (Esen et al., 2011; Vlachopoulos et al., 2011; Tomiyama et al. 2011). Penelitian eksperimental menunjukkan bahwa asam urat mengganggu fungsi endotel melalui reduksi nitrit oksida sintase (eNOS) (Khosla et al., 2005; Tomiyama et al., 2011). Kemudian berdasarkan hasil penelitiannya Tomiyama, (2011) menyimpulkan bahwa hiperurisemia dapat 


\section{WIDYA BIOLOGI}

sebagai faktor risiko independen yang signifikan disfungsi endotel.

Hubungan antara asam urat dengan tekanan darah tinggi, aterosklerosis, penyakit ginjal, penyakit kardiovaskular dan diabetes mellitus ini mungkin memiliki penyebab yang signifikan sehingga menarik perhatian yang tinggi lebih dari setengan abad terakhir. Namun, tidak ada mekanisma yang jelas dimana hiperurisemia dapat menyebabkan penyakit vaskular (Alderman 2008). Kemudian berdasarkan hasil penelitian eksperimental mengungkapkan bahwa asam urat dapat menimbulkan stres oksidatif melalui peningkatan pembentukan spesies oksigen reaktif (ROS) (Sautin et al., 2007; Gaffo and Saag, 2012). Diperkirakan hiperurisemia sebagai faktor risiko penyakit kardiovaskular menyebabkan kerusakan vaskular melalui mekanisma stres oksidatif, sehingga kerusakan vaskular sebagai efek langsung dari hiperurisemia dapat mening-katkan risiko penyakit kardiovaskular.

\section{SERUM ASAM URAT DAN HIPERURISEMIA}

Asam urat ditemukan di tahun 1700-an melalui analisis batu kantung kemih. Kemudian di abad berikutnya tahun 1800-an Sir Archibald Edward Garrod pertama kali menetapkan hubungan antara kadar asam urat tinggi (hiperurisemia) dengan osteoarthritis (Cerezo and Ruilope, 2012). Asam urat adalah senyawa organik dengan rumus umum $\mathrm{C}_{5} \mathrm{~N}_{4} \mathrm{O}_{3} \mathrm{H}_{4}$ merupakan asam organik lemah (pKa 5,8) kelarutannya dalam air kurang baik pada $\mathrm{pH}$ asam. Asam urat dalam tubuh sebagian berasal dari makanan yang dikonsumsi (eksogen) dan sebagian lagi dari hasil biosintesis secara endogen dan di keluarkan melalui saluran pencernaan $(25-30 \%)$ dan melalui ginjal (65-70\%) (Cammalleri and Malaguarnera, 2007). Asam urat merupakan hasil akhir dari degradasi purin baik yang berasal dari eksogen maupun endogen, didegradasi menjadi asam urat melalui hipoxantin dan xantin dikatalisiskan oleh enzim xantin oksidase (XO) yaitu suatu enzim yang mengandung molibdenum (Noriyoshi et al., 2012), terutama dalam hati dan usus (Alderman, 2008). Proses cepat total pool normal asam urat manusia melebihi 1,2 g, kira-kira sepertiganya disekresi melalui saluran empedu yang kemudian didegradasi oleh uricase bakteri usus. Sisanya dikeluarkan oleh ginjal setelah difiltrasi di glomerulus. Eksekresi akhir, ditentukan oleh keseimbangan komplek suatu sistim yang melibatkan reabsorpsi, sekresi dan reabsorpsi sekunder. Proses ini dipengaruhi oleh berbagai faktor meliputi volume ekstraseluler, cepat aliran dan $\mathrm{pH}$ urin, dan aksi dari beberapa hormone. Serum asam urat (SUA) merupakan neto dari produksi dan ekskresinya. Walaupun peningkatan produksi (oleh degradasi seluler atau peningkatan konsumsi purin) dapat menghasilkan hiperurisemia tapi lebih umum merupakan hasil dari penurunan ekskresi atau kombinasi dari keduanya (Emmerson, 1991; Alderman, 2008).

Pada sebagian besar mamalia kecuali manusia dan great apes asam urat didegradasi lebih lanjut menjadi allantoin oleh enzim urikase (urat oksidase) yaitu suatu enzim yang umumnya terdapat dihati. Enzim ini dalam manusia bersifat non aktif karena gen yang mengkodenya mengalami mutasi silencing selama evolusi manusia purba, akibatnya kadar serum asam urat normal pada manusia 


\section{WIDYA BIOLOGI}

jauh lebih tinggi yaitu mendekati 240- 360 $\mu \mathrm{M}(3,5-7,0 \mathrm{mg} / \mathrm{dl})$ dibandingkan pada mamalia lain yaitu mendekati $30-50 \mu \mathrm{M}$ (0,5-1,5 mg/dl) (Feig et al., 2006; So and Thorens, 2010; Schwartz et al., 2011). Beberapa kondisi seperti diet tinggi protein, konsumsi alkohol, siklus sel yang tinggi dan penyakit gagal ginjal dapat menghasilkan kadar asam urat yang tinggi dalam darah (Johnson et al., 2003; Schwartz et al., 2011).<smiles>O=c1[nH]c(=O)c2[nH]c(=O)[nH]c2[nH]1</smiles>

Gambar 1. Struktur Molekul Asam Urat

Sintesis asam urat dalam tubuh, dimulai dari ribose-5-fosfat yaitu suatu pentosa turunan dari metabolisme glysidic, dikonversi menjadi fosforibosil pirofosfat (PRPP) yang kemudian menjadi fosforibosil-amin, dan selanjutnya ditransformasi menjadi inosin monofosfat (IMP). Dari senyawa intermediate/ antara ini menurunkan adenosin monofosfat (AMP) dan guanosin monofosfat (GMP) (suatu nukleotida purin yang digunakan untuk sinthesis DNA dan RNA) serta inosin yang selanjutnya didegradasi menjadi hipoxantin dan xantin dan akhirnya dioksidasi menjadi asam urat dan hidrogen peroksida $\left(\mathrm{H}_{2} \mathrm{O}_{2}\right)$ oleh enzim XO. Hidrogen peroksida merupakan hasil samping yang bersifat racun terhadap ginjal, dikonversi menjadi $\mathrm{H}_{2} \mathrm{O}$ dan $\mathrm{O}_{2}$ oleh enzim katalase (Cammalleri and Malaguarnera, 2007). Hipoxantin dan guanin masuk jalur salvage menggunakan hipoxantin-guanin fosforibosiltransferase (HGPRT), suatu enzim yang merubah kembali basa purin ini menjadi nukleotida (Cammalleri and Malaguarnera, 2007).

\section{ASAM URAT SEBAGAI ANTIOKSIDAN ATAU PRO- OKSIDAN}

Asam urat pada awalnya dikenal sebagai produk limbah yang stabil, mengkristal pada konsentrasi tinggi membentuk batu ginjal dan menyebabkan gouty arthritis. Selanjutnya asam urat dikenal dapat berperan sebagai antioksidan sepenuhnya, dengan kemampuan hampir setengah dari total antioxidant cavacity (TAC) plasma tubuh. Oleh karena itu asam urat diperkirakan dapat membersihkan (scavenges) oksigen tunggal, radikal oksigen, mencegah peroksinitrit, menginduksi protein nitrosasi dan mengkelat logam transisi. Di samping itu juga dapat melindungi LDL dari oksidasi yang dimediasi oleh ion $\mathrm{Cu}^{2+}$. Dengan aksi antioksidan ini, asam urat diperkirakan mendasari efek perlindungan terhadap penyakit kardiovaskular, penuaan dan kanker. Kemudian dari hasil penelitian seluler dan in vitro menunjukkan bahwa, berdasarkan lingkungan mikro kimianya asam urat juga berperan sebagai prooksidan (So and Thorens, 2010).

Asam urat dapat berperan baik sebagai antioksidan atau pro-oksidan tergantung pada lingkungan mikro kimianya. Sebagai antioksidan asam urat memiliki efek yang menguntungkan, tapi pada konsentrasi tinggi memiliki efek yang merugikan (Kutzing and Firestein 2008). Pada konsentrasi fisiologis (normal) berperan sebagai antioksidan, dan pada konsentrasi tinggi (hiperurisemia) berperan 


\section{WIDYA BIOLOGI}

sebagai pro-oksidan. Sebagai pro-oksidan, asam urat dapat meningkatkan oksidasi LDL menghasilkan peroksidasi lipid, mengaktif-kan NADPH oksidase untuk meningkatkan pembentukan ROS. Juga menghambat sintesis NO, dan dalam vascular smooth muscle cell (VSMC) merangsang pembentu-kan monocyte chemoattractant protein-1 (MCP-1), inflamasi dan meningkatkan siklooksigenase 2 (COX-2) untuk membentuk tromboksan, melalui pengaktifan nuclear transcription factor $\left(\mathrm{NF}-{ }_{\mathrm{K}} \mathrm{B}\right)$, dan mitogen activated protein kinase (MAPKs) (Johnson et al., 2003; So and Thorens, 2010). Hal ini juga didukung oleh hasil eksperimen Kanellis et al., (2003) yang menemukankan bahwa asam urat dapat menginduksi jalur inflamasi dalam VSMCs tikus secara in vitro dengan mengaktifkan p 38 MAPK, $\mathrm{NF}_{-\mathrm{K}} \mathrm{B}$, dan AP-1 serta meningkatkan ekspresi COX-2 dan MCP-1. Berdasarkan informasi yang ada, menunjukkan bahwa asam urat memiliki efek biologi dan kimia yang komplek dan pada saat bersifat sebagai pro-oksidan atau reduksi NO, maka dapat menjelaskan hubungan antara hiperurisemia dengan metabolik sindrom dan penyakit kardiovas-kular (Kanellis et al., 2003; So and Thorens, 2010).

\section{ASAM URAT DAN REAKTIF OKSIGEN SPESIES (ROS)}

Asam urat merupakan produk akhir dari metabolisma purin dalam manusia. Dua reaksi terakhir dari reaksi berantai biokimia menghasilkan pembentukan asam urat, yaitu konversi hipoxantin menjadi xantin dan xantin menjadi asam urat dikatalisiskan oleh enzim xantin oksidoreduktase (XOR) (Harrison, 2002; Glantzounis et al., 2005). Kebanyakan serum asam urat diekskresi dalam urin selama fungsi ginjal tidak terganggu, akan tetapi diet rendah sodium juga memiliki efek meningkatkan net reabsorpsi asam urat dalam tubular proxima, sehingga dengan demikian meningkatkan konsentrasi serum asam urat (Rio and Villamil, 1993; Glantzounis et al., 2005).

Asam urat dapat berada secara intraselular dan dalam seluruh cairan tubuh dengan kadar yang lebih rendah dari kadar dalam plasma. Pada $\mathrm{pH}$ fisiologis hampir seluruh asam urat terionisasi menjadi ion urat dengan muatan negative satu (Halliwell and Gutteridge, 1999; Glantzounis et al., 2005). Karena kelarutannya terbatas dalam air, kelebihan produksi secara in vivo dapat menyebabkan pengendapan kristalnya, seperti pada penderita gout, dimana terjadi akumulasi kristal urat dalam sendi menyebabkan arthritis (Glantzounis et al., 2005).

Asam urat pada konsentrasi tinggi dapat menimbulkan stress oksidatif dengan meningkatkan pembentukan ROS melalui reaksi oksidasi secara enzimatis dengan tiga jalur utama yaitu jalur sistim enzim xantin oksidase (XO), jalur NADPHoksidase dan jalur sistim enzim oksida nitrat sintase endotel (eNOS). Pada jalur sistim enzim xantin oksidase (XO), produksi asam urat dari oksidasi hipoxantin dan xantin oleh enzim xantin oksidoreduktase (XOR), dimana enzim ini berada dalam dua bentuk yaitu bentuk xantin dehidrogenase (XDH) dan bentuk xantin oksidase (XO). Pada kondisi fisiologis XOR berada terutama dalam bentuk XDH dan memiliki aktivitas yang lebih tinggi untuk dioksidasi oleh nikotin adenine dinukleotida $\left(\mathrm{NAD}^{+}\right)$dari pada oleh oksigen sebagai elektron akseptor, 


\section{WIDYA BIOLOGI}

dalam mengkatalisakan reaksi oksidasi hipoxantin dan xantin menjadi asam urat. Pada kondisi patologis misalnya iskemia ATP didegradasi menjadi adenine dan xantin, dan pada saat yang sama ada peningkatan konversi XDH menjadi XO. Akibatnya, XO menggunakan molekul oksigen sebagai penerima elektron dalam mengkatalisakan reaksi oksidasi hipoxantin dan xantin menjadi asam urat selama reperfusi. Hal ini menyebabkan terbentuk-nya radikal bebas anion superoksida $\left(\mathrm{O}_{2}^{-}\right) \quad$ (Kooij, 1994; Glantzounis et al., 2005). Anion superoksida dapat membentuk hydrogen peroksida $\left(\mathrm{H}_{2} \mathrm{O}_{2}\right)$ melalui aktivitas enzim superoksida dismutase (SOD) sebagai berikut:

$2 \mathrm{O}^{\cdot 2-}+2 \mathrm{H}^{+} \stackrel{\mathrm{SOD}}{\longrightarrow} \mathrm{H}_{2} \mathrm{O}_{2}+\mathrm{O}_{2}$

dan dengan adanya ion besi (Fero) anion superoksida dapat menjadi radikal hidroksil $\left(\mathrm{OH}^{*}\right)$ yang sangat reaktif melalui reaksi Fenton (Halliwell and Gutteridge, 1999; Glantzounis et al., 2005) sebagai berikut:

$\mathrm{H}_{2} \mathrm{O}_{2}+\mathrm{Fe}^{2+} \rightarrow \mathrm{OH}^{-}+\mathrm{OH}^{-}+$ $\mathrm{Fe}^{3+}$

Melalui jalur sistim enzim NADPH-oksidase, asam urat terlarut merangsang peningkatan aktivitas NADPH-oksidase dan menghasilkan ROS yaitu dengan mentran-sfer elektron kepada molekul oksigen $\left(\mathrm{O}_{2}\right)$ membentuk ion superoksida $\left(\mathrm{O}_{2}{ }^{-{ }^{-}}\right)$dalam adiposit. Perangsangan NADPH-oksidase oleh asam urat mengakibatkan aktivasi MAP kinase p38 dan ERK1/2, penurunan ketersediaan NO, dan peningkatan protein nitrosilasi dan oksidasi lipid (Sautin et al., 2007). Berdasarkan hasil-hasil penelitiannya Sautin et al., (2007) menyimpulkan bahwa hiperurisemia menginduksi sinyal redoxdependent dan stres oksidatif pada adiposit. Dalam vaskular NADPHoksidase menghasilkan ROS yaitu dalam endotel, adventisial dan VSMC. NADPHoksidase mengkata-lisiskan produksi $\mathrm{O}_{2}^{\circ}$ dengan reduksi satu elektron pada oksigen menggunakan $\mathrm{NAD}(\mathrm{P}) \mathrm{H}$ sebagai donor elektron dengan reaksi :

$\mathrm{O}_{2}+\mathrm{NAD}(\mathrm{P}) \mathrm{H} \rightarrow \mathrm{O}_{2}^{-}+\mathrm{NAD}(\mathrm{P})+$ $\mathrm{H}^{+}$(Lassegue and Clempus, 2003; Touyz, 2004).

Sistim enzim yang ketiga yang menghasilkan stres oksidatif adalah sistim enzim oksida nitrit sintase endotel (eNOS). Pada sistim enzim ini, asam urat menurunkan aktivitas eNOS dengan menurunkan transfort arginin melalui pengaktifan arginase yang dapat mengalihkan arginin dari sintesis NO oleh eNOS ke sintesis urea menyebabkan disfungsi endotel (So and Thorens, 2010). Arginin merupakan satu-satunya substrat untuk sintesis NO oleh eNOS pada sel endotel (Zharikov et al., 2008). Ketika sumber arginin berkurang, maka fungsi eNOS berubah menjadi enzim pembentuk superoksida yang disfungsional, menyebab-kan akumulasi pembentukan ROS, karena eNOS lepas (uncoupling) dengan 4 gugus prostetik redok aktifnya yaitu FAD, FMN, heme dan $\mathrm{BH}_{4}$ yang dapat mentransfer elektron kepada $\mathrm{O}_{2}$ membentuk superoksida $\left(\mathrm{O}_{2}{ }^{-}\right.$/ROS $)$ (Schwartz et al., 2011; Samant, et al., 2012).

\section{HIPERURISEMIA, METABOLIK SINDROM AND PENYAKIT KARDIOVASKULAR}

Metabolik sindrom (MS) sebagai prediksi penyakit kardiovaskular telah dikenal secara luas (Wilson et al., 2005; Borges et al., 2010). Akan tetapi hubungan antara asam urat dengan penyakit 


\section{WIDYA BIOLOGI}

kardiovas-kular relatif masih banyak dipertentangkan (Feig et al., 2008). Pandangan lama beranggapan bahwa hiperurisemia disebab-kan oleh gangguan ginjal dalam eksekresi asam urat sebagai kompensasi dari hiperinsulinemia (Facchini et al., 1992; Borges et al., 2010). Sedangkan penelitian akhir-akhir ini memberikan persepektif yang berbeda, dan menyimpulkan bahwa asam urat dapat memperediksi secara independen MS dan diabetes. Juga ditambahkan bahwa hubungan antara hiperurisemia dan MS adalah bebas dari perkiraan glomerular filtration rate (GFR). Hal ini menunjukkan bahwa fungsi ginjal tidak terkait dengan hubungan antara hiperurisemia dengan MS (See et al., 2009; Borges et al., 2010). Dari hasil eksperimen terhadap hewan coba menunjukkan bahwa, peningkatan kadar asam urat menyebabkan MS dan menghambat fungsi endotel, serta menghambat ketersediaan NO, di mana kecukupan akan kadar NO penting bagi aksi insulin untuk mendorong penyerapan glukosa (Johnson et al., 2009; Borges et al., 2010). Dengan terhambatnya fungsi endotel, maka terhambat pula penyerapan glukosa darah. Berdasarkan hasil eksperimen ini menunjukkan bahwa, hiperurisemia bukan merupakan akibat dari insulin resisten, tetapi merupakan penyebab. Peneliti lain seperti Ishizaka et al., (2005) juga menemukan bahwa, konsentrasi asam urat terkait dengan MS. Bahkan Ford et al., (2007) menemukan pada orang Amerika antara anak-anak sampai remaja, konsentrasi serum asam urat sangat terkait dengan prevalensi MS dan beberapa komponennya. Demikian juga bukti mengenai hubungan antara konsentrasi asam urat yang tinggi dengan hipertesi dan faktor risiko kardiovaskular yang lain adalah cukup luas (Cerezo and Ruilope, 2012). Penelitian eksperimen lain yaitu inkubasi sel-sel otot polos vascular (VSMC) dengan asam urat juga menunjukkan bahwa asam urat menyebabkan ketidak normalan endotel yang dimediasi oleh mediator potensial yaitu sistim rennin angiotensin. Asam urat menyebabkan proliferasi endotel, produksi angiotensin II dan peningkatan marker stres oksidatif. Kemudian efek ini dapat dihilangkan dengan pemberian captopril atau losartan (Corry et al., 2008; Gaffo and Saag, 2012). Demikian juga ketidak normalan hemodinamik endotel pada tikus hiperurisemia juga dapat dikembalikan dengan pemberian scavenger superoksida. Hal ini mendukung keterkaitan antara tingginya kadar asam urat dan kerusakan yang disebabkan oleh spesies oksigen reaktif (stress oksidatif) (Sanches-Lozada et al., 2008; Gaffo and Saag, 2012).

Mekanisma stres oksidatif dalam hubungan antara hiperurisemia dengan MS, bahwa asam urat yang tinggi dapat menginduksi stres oksidatif dalam berbagai sel, seperti yang ditunjukkan dalam adiposit yang menyebabkan MS. Berdasarkan hal tersebut, maka beralasan untuk menduga bahwa hiperurisemia mampu mendorong keadaan insulin resisten, dan membenarkan risiko kardiovaskular lebih kuat terkait dengan kadar asam urat yang lebih tinggi. Hiperurisemia sebagai faktor risiko penyakit kardiovaskular terkait dengan aktivitas inflamasi, aktivasi sistim rennin angiotensin aldosteron (RAAS), disfungsi endotel, proliferasi vascular smooth muscle cell (VSMC) dan tingginya tekanan darah (Borges et al., 2010). 


\section{WIDYA BIOLOGI}

\section{ROS DALAM KERUSAKAN VASKULAR}

Ada bukti substansial bahwa stress oksidatif terlibat dalam patofisiologi penyakit kardiovaskular. Penelitian biokimia, molekuler dan farmakologi selanjutnya melibatkan XOR sebagai sumber ROS dalam sistim kardiovaskular (Berry and Hare, 2004; Glantzounis et al., 2005). Stres oksidative secara luas dianggap sebagai mediator dalam proses perkembangan dan kemajuan komplikasi kardiovaskular seperti penyakit arteri koroner (CAD)(Sorescu and Griendling, 2002) dan gagal jantung (Byrne et al., 2003; Glantzounis et al., 2005). Stres oksidatif juga dapat memainkan peran dalam fatogenesis dari diabetes yang terkait dengan disfungsi kardiak, disfungsi dan kerusakan vascular secara umum (Glantzounis et al., 2005).

Metabolisma oksigen oleh sel dapat menghasilkan ROS yang secara potensial merugikan. Pada kondisi normal kecepatan pembentukan oksidan adalah seimbang dengan kecepatan penghilangan oksidan itu sendiri, atau keseimbangan antara prooksidan dan antioksidan. Apabila terjadi ketidak seimbangan antara prooksidan dan antioksidan akan mengakibatkan stres oksidatif, yang merupakan hasil pathogen dari oksidan berlebihan yang melampaui kapasitas antioksidan seluler. Pembuluh darah merupakan sumber yang kaya NADPH oksidase yang menghasilkan ROS, yang dalam kondisi patologis memainkan peran penting dalam kerusakan pembuluh darah (Touyz, 2004).

ROS vascular dihasilkan dalam endotel, adventisial dan VSMC yang berasal dari $\mathrm{NAD}(\mathrm{P}) \mathrm{H}$ oksidase yang merupakan enzim multisubunit mengkatalisiskan produksi $\cdot \mathrm{O}_{2}^{-}$dengan reduksi satu electron pada oksigen menggunakan $\mathrm{NAD}(\mathrm{P}) \mathrm{H}$ sebagai donor electron dengan reaksi : $2 \mathrm{O}_{2}+\mathrm{NAD}(\mathrm{P}) \mathrm{H}$ $\rightarrow 2 \mathrm{O}_{2}^{-}+\mathrm{NAD}(\mathrm{P})+\mathrm{H}^{+}$(Lassegue and Clempus, 2003; Touyz, 2004). $\mathrm{NAD}(\mathrm{P}) \mathrm{H}$ oksidase vascular terdiri dari palingsedikit 4 komponen: terkait membran sel p22phox dan gp91phox (atau gp91phox [nox2] homolog, nox1 dan nox4), dan subunit sitosol, p47phox dan p67phox. NAD $(\mathrm{P}) \mathrm{H}$ oksidase vascular diatur oleh humoral (cytokins, growth factor dan vasoactive agents) dan factor fisik (elastis, regangan berdenyut dan tegangan geser) (Lassegue and Clempus, 2003; Touyz, 2004). Secara fisiologi ROS dihasilkan secara terkendali dalam konsentrasi rendah dan berfungsi sebagai molekul sinyal untuk menjaga integritas pembuluh darah dengan mengatur fungsi endotel dan kontraksi-relaksasi vascular (Touyz et al., 2003; Touyz, 2004). Dalam kondisi patologis peningkatan bioaktivitas ROS menyebabkan disfunsi endotel, peningkatan kontraktilitas, pertumbuhan VSMC, invasi monosit, peroksidasi lipid, inflamasi dan peningkatan pengendapan matrik protein ekstraseluler yang merupakan faktor penting kerusakan vascular dan hipertensi (Taniyama and Griendling, 2003; Touyz, 2004). Proses molekuler yang mendasari ROS menginduksi perubahan vascular melibatkan aktivasi jalur sinyal redoks sensitive. Anion superoksida dan $\mathrm{H}_{2} \mathrm{O}_{2}$ merangsang mitogen diaktivasi protein kinase, tirosin kinase dan faktor transkripsi $\left(\mathrm{NF}_{\mathrm{K}} \mathrm{B}, \mathrm{AP}-1\right.$, dan HIF-1) dan inaktivasi protein tirosin fosfatase (Chiarugi and Cirri, 2003; Touyz, 2004). ROS juga meningkatkan $\left[\mathrm{Ca}^{2+}\right]_{\mathrm{i}}$ dan meningkatkan pengaturan protonongkogen dan ekspresi 


\section{WIDYA BIOLOGI}

gen proinflamasi. Proses ini terjadi melalui modifikasi protein oksidatif dengan mengubah residu asam amino penting, dengan induksi dimerisasi protein, dan dengan berinteraksi dengan kompleks logam seperti gugus Fe-S. Perubahan kondisi redoks intraseluler melalui sistem thioredoksin dan glutation juga dapat mempengaruhi terjadinya sinyal (Chiarugi and Cirri, 2003; Touyz, 2004).

\section{SIMPULAN}

Hiperurisemia sebagai faktor risiko penyakit kardiovaskular dengan memberikan efek vaskular secara langsung dan menyebabkan kerusakan vaskular melalui mekanisma peningkatan pembentukan ROS (stres oksidatif). ROS menginduksi perubahan vaskular melalui aktivasi jalur sinyal sensitif redoks mengaktifkan mitogen activated protein kinase (MAPKs), tirosin kinase dan faktor transkripsi $\left(\mathrm{NF}_{\mathrm{K}} \mathrm{B}, \mathrm{AP}-1\right.$, dan HIF-1) merangsang pembentukan monocyte chemoattractant protein-1 (MCP-1), inflamasi dan meningkatkan siklooksigenase 2 (COX-2).

\section{DAFTAR PUSTAKA}

Alderman, M.H. 2008. Hyperuricemia and Vascular Damage. Hot Topics in Cardiology 14:7-13.

Berry, C.E., Hare, J.M. 2004. Xanthine oxidoreductase and Cardiovascular Disease: Molecular mechanisms and Pathophysiological Implications. $J$ Physiol 555(Pt 3):589-606.

Borges, R.L., Ribeiro, A.B., Zanella, M.T., Batista, M.C. 2010. Uric Acid as a Factor in the Metabolic Syndrome. Curr Hypertens Rep. 12:113-119.
Byrne, J.A., Grieve, D.J., Cave, A.C., Shah, A.M. 2003. Oxidative Stress and Heart Failure. Arch Mal Coeur Vaiss 96:214-221.

Cammalleri, L. and Malaguarnera, M. 2007. Rasburicase Represents a New Tool for Hyperuricemia in Tumor Lysis Syndrome and in Gout. International Journal of Medical Sciences 4(2):83-93.

Cerezo, C., Ruilope, L.M. 2012. Uric Acid and Cardiovascular Risk Considered: an Update. An article from the e-journal of ESC Council for cardiology Practice 10 Available from:URL:http://www.escardio.org / communities/ councils/ccp/ ejournal/volume 10.

Chiarugi, P., Cirri, P. 2003. Redox Regulation of Protein Tyrosine Phosphatases During Receptor Tyrosine Kinase Signal transduction. Trends Biochem Sci. 28:509-514.

Corry, D.B., eslami, P., Yamamoto, K., Nyby, M.D., Makino, H., Tuck, M.L. 2008. Uric Acid Stimulates Vascular Smooth Muscle Cell Proliferation and Oxidative Stress via the Vascular Renin-angiotensin System. J. Hypertens 26(2):269-75.

Emmerson, B.T. 1991. Identification of Causes of Persistent Hyperuricemia. Lancet 337:14611463.

Esen, A.M., Akcakoyun, M., Esen, O., Acar, G., Emiroglu, Y., Pala, S., Kargin, R., Karapinar, H., Ozcan, O., Barutcu, I. 2011. Uric Acid as a Marker of Oxidative Stress in 


\section{WIDYA BIOLOGI}

Dilatation of the Ascending Aorta. Am. J. Hypertens 24:149-154.

Facchini, F., Chen Y.D., Hollenbeck, C.B. Reaven, G.M. 1992. Relationship between resistance to insulinmediated glucose uptake, urinary uric acid clearance, and plasma uric acid concentration. Circulation 112:3066-3072.

Feig, D.I., Kang, D.H., and Johnson, R.J. 2008. Uric Acid and Cardiovascular Risk. The New England Journal of Medicine 359:1811-1821.

Feig, D.I., Mazzali, M., Kang, D.H., Nakagawa, T., Price, K., Kannelis, J., and Johnson, R.J. 2006. Serum Uric Acid: a Risk Faktor and a Target for Treatment ?. J Am Soc Nephrol 17:S67-S73.

Ford, E.S., Li, C., Cook, S. and Choi, H.K. 2007. Serum Concentrations of Uric Acid and the Metaboloc Syndrome Among US Children and Adolescents. Circulation 115:2526-2532.

Gaffo, A.L. and Saag, K.G. 2012. Drug Treatment of Hyperuricemia to Prevent Cardiovascular Outcomes. Am. J. Cardiovasc Drugs 12(1):16.

Gagliardi, A.C., Miname, M.H., Santos, R.D. 2009. Uric Acid: A Marker of Increased Cardiovascular Risk. Artherosclerosis 202:11-17.

George, J. and Struthers, A.D. 2009. Role of Urate, Xanthine Oxidase and the Effects of Allopurinol in Vascular Oxidative Stress. Vascular Health and Risk Management 5:265-272.

Glantzounis, G.K., Tsimoyiannis, E.C., Kappas, A.M. and Galaris, D.A.
2005. Uric Acid and Oxidative Stress. Current Pharmaceutical Design 11:4145-4151.

Halliwel, B., Gutteridge, J. 1999. Free Radical in Biology and Medicine. Third ed. New York: Oxford University Press.

Harrison, R. 2002. Structure and Function of Xanthine Oxidoreductase: Where are We Now?. Free Radic Biol Med. 33:774-797.

Ishizaka, N., Ishizaka, Y., Toda, E.I., Nagai, R. and Yamakado, M. 2005. Arteriosclerosis, Thrombosis, and Vascular Biology. Journal of the American Heart Association 25:1038-1044.

Jackson, R.L., Hunt, B. and MacDonald, P.A. 2012. The Efficacy and Safety of Febuxostat for Urat Lowering in Gout Patients $\geq 65$ Years of Age. BMC Geriatrics. 12:11

Johnson, R.J., Kang, D.H., Feig, D., Kivlighn, S., Kanelis, J., Watanabe, S., Tuttle, K.R., Iturbe, B.R., Acosta, J.H., Mazzali, M. 2003. Is There a Pathogenetic Role for Uric Acid in Hypertention and Cardiovascular and renal Disease? Hypertension. 41:1183-1190.

Johnson, R.J., Perez-Pozo S.E., Sautin Y.Y., Manitius J., Sanchez-Lozada L.G., Feig, D.I., Shafiu M., Segal M., Glassock R.J., Shimada M., Roncal C., and Nakagawa T. 2009. Hypothesis: Could Excessive Fructose Intake and Uric Acid Cause Type 2 Diabetes? Endocr. Rev. 30(1):96-116.

Kanbara, Y., Hakoda, M., Seyama, I. 2010. Urin Alkalisazation 


\section{WIDYA BIOLOGI}

Facilitates Uric Acid excretion. Nutrition Journal 9:45.

Kanellis, J., Kang, D.H. 2005. Uric Acid as a Mediator of Endothelial Dysfunction, Inflammation, and Vascular Disease. Semin Nephrol. 25(1):39-42.

Khosla, U.M., Zharikov, S., Finch, J.L., Nakagawa, T., Roncal, C., Mu, W., Krotova, K., Block, E.R., Prabhakar, S., Johnson, R.J. 2005. Hyperuricemia Induces Endothelial Dysfunction. Kidney Int 67:1739-1742.

Kooij, A. 1994. A Re-evaluation of the Tissue Distribution and Physiology of Xanthine Oxidoreductase. Histochem $J$ 26:889-915.

Kutzing, K. and Firestein, B.L. 2008. Altered Uric Acid level and Disease States. The Journal of Pharmacology and Experimental Therapeutics 324(1):1-7.

Lassegue, B., Clempus, R.E. 2003. Vascular NAD(P)H Oxidase: Specipic Features, Expression, and Regulation. Am J Physiol Regul Integr Comp Physiol 285:R277-R297.

Nakagawa, T., Kang, D.H., Feig, D., Lozada, L.G.S., Srinivas, T.R., Sautin, Y., Ejaz, A.A., Segal, M. and Johnson, R.J. 2006. Unearthing Uric Acid: An Ancient Factor with Recently Found Significance in Renal and Cardiovascular Disease. Kidney International 69:1722-1725.
Noriyoshi, M., Ken-ichi, N., Takayoshi, M., Kouhei, K., Kenji, S., Isao, K. 2012. The Inhibition of Uric Acid Formation Catalyzed by Xanthine Oxidase Properties of Alkil Caffeates and Cardol. Journal of Food Research.1(3):257-262.

Oliveira, E.P.d. and Burini, R.C. 2012. High Plasma Uric Acid Concentration: Causes and Consequences. Diabetology \& Syndrome. 4:12.

Rio, D.A., Villamil, R.J.L. 1993. Metabolic Effects of Strict Salt Restriction in essential Hypertensive Patients. J Intern Med 233:409-414.

Samant, P., Badade, Z.G., Rai, S. 2012. Effect of Hyperuricemia on Serum Nitric Oxide Levels in Diabetic Patients with Hyperlipidemia. Int. J. Biol. Med. Res. 3(1):1338-1341.

Sanchez-Lozada, L.G., Tapia, E., Santamaria, J. 2005. Mild Hyperuricemia Induces Vasoconstriction and Maintains Glomerular Hypertension in Normal and Ramnant Kidney Rats. Kidney Int 67(1):237-247.

Sautin, Y.Y., Nakagawa, T., Zharikov, S. and Johnson, R.J. 2007. Adverse Effects of the Classic Antioxidant Uric Acid in Adipocytes: NADPH Oxidase-mediated

Oxidative/Nitrosative Stress. Am. J. Physiol Cell Physiol 293:C584C596.

Schwartz, I.F., Grupper, A., Chernichovski, T., Grupper, A., Hillel, O., Engel, A., Schwartz, D. 2011. Hyperuricemia Attenuates 


\section{WIDYA BIOLOGI}

Aortic Nitric Oxide Generation, through Inhibition of Arginine Transport, in Rats. J. Vasc. Res. 48:252-260.

$\mathrm{See}_{2}$ LC., Kuo, C.F., Chuang, F.H., Li, H.Y., Chen, Y.M., Chen, H.W., $\mathrm{Yu}_{2}$ K.H. 2009. Serum uric acid is independently associated with metabolic syndrome in subjects with and without a low estimated glomerular filtration rate. $J$. Rheumathol 36(8):1691-1698.

Shadidi, F. 2000. Natural Antioxidants: Source, Effects and Applications. Departement of Biochemistry. Memorial University of Newpoundland. St John's. NF. Canada.

So, A. and Thorens, B. 2010. Uric Acid Transport and Disease. Journal of Clinical Investigation. 120(6):1791-1799.

Sorescu, D., Griendling, K.K. 2002. Reactive Oxygen Species, Mitochondria, and NAD(P)H oxidase in the development and Progression of Heart Failure. Congest Heart Fail 8:132-140.

Taniyama, Y., Griendling, K.K. 2003. Reactive Oxygen Species in the Vasculature: Molecular and Cellular Mecanism. Hypertension 42:1075-1081.

Tomiyama, H., Higashi, Y., Takase, B., Node, K., Sata, M., Inoue, T., Ishibashi, Y., Ueda, S., Shimada, K., Yamashina, A. 2011. Relationships Hyperuricemia, Among Sindrome, and Metabolic Function. American Journal of Hypertention 24(7):770-774.
Touyz, R.M. 2004. Reactive Oxygen Species, Vascular Oxidative Stress, and Redox Signaling in Hypertension: What is the Clinical Significance?. Hypertension 44:248252.

Touyz, R.M., Tabet, F., Schiffrin, E.F. 2003. Redox-dependent Signalling by Angiotensin II and Vascular Remodelling in Hypertension. Clin Exp Pharmacol Physiol. 30:860-866.

Vlachopoulos, C., Xaplanteris, P., Vyssoulis, G., Bratsas, A., Baou, K., Tzamou, V., Aznaouridis, K., Dima, I., Lazaros, G., Stefanadis, C. 2011. Association of Serum Uric Acid Level with Aortic Stiffness and Arterial Wave Reflections in Newly Diagnosed, Never-Treated Hypertention. Am. J. Hypertentions 24:33-39.

Wallace, K.L., Riedel, A.A., JosephRidge, N., Wortmann, R. 2004. Increasing Prevalence of Gout and Hyperuricemia over 10 Years Among Older Adults in a Managed Care Population. J. Rheumatol. 31(8):1582-1587.

Wilson, P.W.F, D’Agostino, R.B., Parise, H., Sullivan, L., Meigs, J.B. 2005. Metabolic Syndrome as a Precursor of Cardiovascular Disease and Type 2 Diabetes Mellitus. Circulation 112:30663072 .

Zharikov, S., Krotova, K., Hu, H., Baylis, C., Johnson, R.J., Block, E.R. and Patel, J. 2008. Uric Acid Decreases NO Production and Increases Arginase Activity in Cultured Pulmonary Artery Endothelial Cells. Am. J. Physiol Cell Physiol 295:C1183-C1190. 